\title{
Ortopedi Hastalarının Malnütrisyon Durumları ve Risk Faktörlerinin Belirlenmesi
}

\section{Determination of Malnutrition Status and Risk Factors in Orthopedic Patients}

\author{
Hale Turhan Damar ${ }^{1 *}$, Ayşegül Savcı², Özlem Bilik ${ }^{3}$ \\ ${ }^{1}$ İzmir Demokrasi Üniversitesi, Sağlık Hizmetleri Meslek Yüksekokulu, Yaşlı Bakım Programı, İzmir, Türkiye. \\ ${ }^{2}$ Kütahya Sağlık Bilimleri Üniversitesi, Sağlık Bilimleri Fakültesi, Hemşirelik Bölümü, Kütahya, Türkiye. \\ ${ }^{3}$ Dokuz Eylül Üniversitesi, Hemşirelik Fakültesi, Cerrahi Hastalıkları Hemşireliği, İzmir, Türkiye.
}

e-mail: hale.turhan1986@gmail.com, agulsvc@gmail.com, ozlemdeuhf2011@gmail.com

ORCID: 0000-0002-1218-5319

ORCID: 0000-0002-9176-7420

ORCID: 0000-0002-8372-8974

*Sorumlu yazar/ Corresponding Author: Hale Turhan Damar

Gönderim Tarihi / Received: 15.02.2021

Kabul Tarihi / Accepted: 19.03.2021

DOI: $10.34087 /$ cbusbed. 880671

\section{Öz}

Giriş ve Amaç: $\mathrm{Bu}$ çalışmanın amacı ortopedi hastalarının malnütrisyon durumlarının ve risk faktörlerinin belirlenmesidir.

Gereç ve Yöntemler: Kesitsel tipteki çalışma 05/2017 -12/2018 tarihleri arasında XXX hastanesinde Ortopedi ve Travmatoloji Kliniğinde toplam 123 hasta ile gerçekleştirildi. Araştırma verileri, Hasta Tanılama ve Klinik Formu, Nutrisyonel Risk Taraması Ölçeği (Nutritional Risk Screening) kullanılarak toplanmıştır.

Bulgular: Hastaların yaş ortalaması $65,72 \pm 20,79$ dır. Cerrahi girişim geçiren hastaların aç kalma süre ortalamaları ameliyat öncesi 10,82 $\pm 3,20$ saat, ameliyat sonrası ise 11,01 $\pm 10,84$ saattir. Hastaların $\% 31,7$ 'sinin malnütriyon riski altında olduğu ve tamamının beslenme desteği almadığı saptandı. Malnütrisyon riski olan hastaların yaş ortalaması daha yüksekti $(\mathrm{t}=-4,087, \mathrm{p}=0,000)$. Malnütriyon riski olan hastaların ameliyat öncesi aç kalma süreleri, riski olmayanlara göre daha uzundu $(\mathrm{t}=-3,019, \mathrm{p}=0,000)$. Ameliyat olup malnütrisyon riski olan hastaların ameliyat sonrası ilk mobilizasyonları daha uzun sürede gerçekleşmişti $(\mathrm{t}=-4,113, \mathrm{p}=0,000)$. Hastaların albumin değerleri ile NRS skorları arasında istatiksel olarak anlamlı bir fark saptand $1(t=5,751, p=0,000)$. Katılımciların cinsiyet $\left(X^{2}=4,809\right.$ $\mathrm{p}=0,028)$, eğitim düzeyleri $\left(\mathrm{X}^{2}=10,358, \mathrm{p}=0,0016\right)$, kronik hastalık varlığ $1\left(X^{2}=5,890, \mathrm{p}=0,015\right)$ ve enfeksiyonu durumu $\left(\mathrm{X}^{2}=7,566, \mathrm{p}=0,006\right)$ ile NRS skorları arasında istatiksel olarak anlamlı fark saptandı.

Sonuç: Çalışmamızda yaklaşık üç hastadan birinin malnütriyon riski altında olduğu saptanmıştır. Araştırma sonuçları hastaların malnütrisyon riskini etkileyen diğer seçilmiş faktörlerin yaş, cinsiyet, hastaların eğitim düzeyi, komorbit hastalık varlığı, düşük albumin düzeyi, ameliyat öncesi açlık süresi ve ameliyat sonrası enfeksiyon gelişmesi olduğunu göstermiş̧tir. Ayrıca malnütrisyon riski olan hastaların ameliyat sonrası ilk mobilizasyon sürelerinin daha geç olduğu saptanmıştır. Güncel rehberler doğrultusunda, profesyonel bir ekip yaklaşımı ile beslenme desteği yaklaşımları standart haline getirilmelidir.

Anahtar kelimeler: Beslenme Risk Değerlendirmesi, Malnütrisyon, Ortopedi ve Travmatololoji.

\section{Abstract}

Objective: The aim of this study is to determine the malnutrition status and risk factors in orthopedic patients.

Materials and Methods: The cross-sectional study was conducted between 05/2017 and 12/2018 in a university hospital in the west of Turkey Orthopedics and Traumatology Clinic with 123 patients. Research data were collected using the Patient Diagnosis and Clinical Form, Nutritional Risk Screening (NRS).

Results: The average age of the patients is $65.72 \pm 20.79$. The average fasting time of patients who underwent surgery was $10.82 \pm 3.20$ hours before surgery and $11.01 \pm 10.84$ hours after surgery. It was found that $31.7 \%$ of the patients were under the risk of malnutrition and not all of them received nutritional support. The mean age of the patients with 
malnutrition risk was higher $(\mathrm{t}=-4.087, \mathrm{p}=0.000)$. Patients with malnutrition risk had longer periods of fasting before surgery than those without risk $(\mathrm{t}=-3.019, \mathrm{p}=0.000)$. Patients who had undergone surgery and had malnutrition risk had their first mobilization in a longer period after surgery $(\mathrm{t}=-4.113, \mathrm{p}=0.000)$. A statistically significant difference was found between the patients' albumin values and NRS scores $(t=5.751, p=0.000)$. A statistically significant difference was found between the participants' gender $\left(X^{2}=4.809 \mathrm{p}=0.028\right)$, education level $\left(\mathrm{X}^{2}=10.358, \mathrm{p}=0.0016\right)$, presence of chronic disease $\left(\mathrm{X}^{2}=5.890, \mathrm{p}=0.015\right)$ and infection $\left(\mathrm{X}^{2}=7.566 .5, \mathrm{p}=0.006\right)$ and their NRS scores.

Conclusion: In our study, it was found that approximately one out of three patients was at risk of malnutrition. Our research results showed that other risk factors affecting the malnutrition risk of patients are age, gender, education level of the patients, presence of comorbid disease, low albumin level, preoperative fasting period and postoperative infection development. In addition, it was found that the first postoperative mobilization period of patients with malnutrition risk was later. Nutritional support approaches should be standardized with a professional team approach in line with current guidelines.

Keywords: Malnutrition, Nutritional Risk Screening, Orthopedics ve Traumatology.

\section{Giriş}

Ortopedik girişim uygulanan bireylerde malnütrisyon durumu ele alınması gereken ancak ihmale uğrayabilen önemli bir sorundur [1,2]. Yetersiz gida alımına bağlı olarak ortaya çıkan malnütrisyon, bireyde fiziksel ve mental fonksiyonların gerilemesi ve iyileşmenin bozulmasına yol açan, aynı zamanda vücut kompozisyonunda değişikliklerin oluşumuna neden olan bir tablodur [3,4]. Hastalar hastaneye yattıktan sonra malnütrisyon ile karşılaşabildiği gibi var olan bir malnütrisyon ile de hastaneye yatmış olabilir [5,6]. Malnütrisyon, hastanede yatan hastalarda $\% 12$ ile $\% 50$ oranlarında görülebilmektedir [7,8]. Malnütrisyon hastanede yatan ve cerrahi işlem geçiren hastalarda hastanede yatış süresinin uzamasına, hastaneye tekrar yatışların, enfeksiyon oranlarının ve mortalitenin, artmasına neden olmaktadır [9,10]. Bu sonuçlar hastaların sağlık bakım maliyetlerini artırmaktadır [11]. Geriatrik ortopedi hastalarındaki malnütrisyon insidans $\% 32$ ile \%60 arasındadır [1,12]. Kalça kırıkları sonrasında ilk bir yıl içindeki mortalitenin malnütrisyon ile ilişkisi olduğu belirlenmiştir [2]. Ayrıca, total eklem protezi uygulanmış hastalarda malnütrisyonun belirleyicilerinden olan hipoalbumineminin hastanede kalış süresi, yeniden hastaneye yatış, pnömoni ve cerrahi alan enfeksiyonlarını olumsuz etkileyen bir faktör olduğu belirtilmektedir [13]. Malnütrisyon riski belirlenen ortopedi hastalarında hastanede yatış süresinin uzadığı ve mobilizasyonlarının geciktiği de bildirilmiştir [1]. Hastaneye yatıştan itibaren hastaların beslenme durumlarının değerlendirilerek yetersizliğin erken fark edilmesi ile pnömoni, uzamış yara iyileşmesi ve enfeksiyonu, sepsis ve mortalite gibi perioperatif komplikasyon risklerinin azaltılabileceği bildirilmektedir $[1,14]$. Avrupa Klinik Nutrisyon ve Metabolizma Derneği'nin (European Society for Clinical Nutrition and Metabolism, ESPEN) ve Amerika Birleşik Devletleri sağlık kuruluşları hastanın hastaneye kabulünden sonraki ilk 24 saat içinde beslenme durumunun değerlendirilmesi ve beslenmeyle ilgili risklerin belirlenmesini önermektedir [3]. Ancak ameliyata hazırlanan hastalarda nutrisyonel değerlendirme etkin yapılmamaktadır [8]. Ortopedi ve Travmatoloji kliniklerinde de hastalarda malnütrisyon tanılaması ve tedavisinde yetersizlikler olabilmektedir [1,2]. Ortopedi hastaları genellikle yaşlı ve majör cerrahi girişim yapılan hastalar olup beslenme durumlarının değerlendirilmesi cerrahi girişimin ve iyileşmenin etkinliği açısından önemlidir. Ancak kliniklerde geleneksel uygulamalar sürdürülmekte ve hastaneler arasında çok farklı sonuçlar ortaya çıkabilmektedir. Tüm cerrahi kliniklerinde, beslenme yetersizliğinin taranması ve etkileyen faktörlerin ortaya çıkarılmasının, kanıta dayalı standartların geliştirilmesi için bir ön çalışma olacağı düşünülmektedir. $\mathrm{Bu}$ çalışmanın amacı ortopedi hastalarının malnütrisyon durumlarını ve risk faktörlerinin belirlenmesidir.

\section{Materyal ve Metot}

Araştırma kesitsel tanımlayıcı olarak gerçekleştirilmiş̧tir. Araştırma, XXX hastanesinin Ortopedi ve Travmatoloji Kliniği'nde Mayıs 2017- Aralık 2018 tarihleri arasında yürütülmüştür.

Araştırmanın örneklemini, araştırma verilerinin toplandığ1 tarihte XXX hastanesinin Ortopedi ve Travmatoloji Kliniği'nde tedavi gören ve örnekleme alınma ölçütlerine uyan bireyler oluşturmuştur. Bireylerin örnekleme alınma ölçütleri arasında; 18 yaşından büyük olması, ortopedik ameliyat uygulanması, Türkçe anlayabilmesi ve konuşabilmesi, kişi, yer ve zaman oryantasyonu olması, işitme ve konuşma sorunu olmaması ve araştırmaya gönüllü olarak katılmayı kabul etmesidir. Çalışmadan dışlanma ölçütü ise; bilişsel durumu etkileyen nörolojik (demans/alzhemier gibi) ve psikiyatrik (şizofreni gibi) tıbbi tanısının bulunması ve yoğun bakımda yatıșı olmasıdır.

Bu çalışmada örneklem büyüklüğü hesaplamasında $G^{*}$ powersoftware, version 3.1 kullanılmıştır. Ihle ve arkadaşlarının araştırmasındaki [1] veriler kullanılarak ve standart sapmanın 0,2'si en düşük etki olarak belirlenerek örneklem büyüklüğü, $\% 80$ güç, $\% 95$ güven aralığında 0,05 hata payı ile NCSS-PASS yazılım programında toplam 116 hasta olarak hesaplanmıştır. Çalışma 123 hastadan alınan veriler ile tamamlanmıştır.

\subsection{Veri Toplama Araçları}

Araştırma verileri; Hasta Tanılama ve Klinik Formu, Nutrisyonel Risk Taraması Ölçeği kullanılarak toplanmıştır. Hasta tanılama formunda; hastaların yaşı, cinsiyeti, eğitim durumu, tanısı, ameliyat olma durumu, ameliyat tipi, ameliyat sonrası gün sayısı, ek hastalık varlığı, BKİ, diyet uygulama durumu, sigara kullanma durumu, günlük sigara sayısı, sigara kullanma süresi, NRS skoru, preoperatif aç kalma süresi, postoperatif aç 
kalma süresi, postoperatif mobilizasyon zaman1, enfeksiyon varlığı, albumin düzeyi, beslenme desteği alma durumuna ilişkin sorular yer almaktadır. Hasta tanılama formu ilgili literatür bilgilerinden yararlanılarak araştırmacılar tarafından geliştirilmiştir [1,6,13,15].

Hastaların beslenme durumlarının değerlendirilmesinde kullanılan birçok form vardır. Bu formlardan birisi de Nutrisyonel Risk Taraması Ölçeği (NRS-2002) olup, erişkin hastalarda beslenme yetersizliği riskindeki hastayı tanılamak amaciyla yaygın olarak kullanılmaktadır [4,15-17]. Nutrisyonel Risk Taraması Ölçeği (NRS-2002), Avrupa Klinik Nutrisyon ve Metabolizma Derneği'nin [European Society for Clinical Nutrition and Metabolism, ESPEN] hastanede yatan hastalarda kullanılmasını önerdiği kapsamlı tarama testlerinden biridir [4]. Yapılan çalışmalarda ortopedi hastalarının nütrisyonel değerlendirilmesinde NRS-2002 yaygın olarak kullanılmaktadır [15,16]. İki bölümden oluşmakta olup, birinci bölümde dört soru vardır. Bu sorulardan herhangi birine evet cevabı verilirse ikinci bölüme geçilir. Eğer dört soruya da hayır cevabı verilirse test hastanede yattığ 1 sürece haftada bir kez tekrarlanır. İkinci bölüm, nutrisyon durumundaki bozulma ve hastalık şiddeti bölümü olarak iki ana başlıktan oluşmaktadır. Her iki başlık altındaki sorular toplamı en fazla 3 puan ve her iki bölüm toplamda 6 puan değerindedir. Eğer hasta 70 yaşın üzerinde ise bu puana bir puan daha eklenerek hastanın toplam NRS puanı elde edilir. Toplam skor $\geq 3$ ise hasta nütrisyon riski altındadır ve bir nütrisyon planı başlatılmalıdır anlamına gelmektedir. Toplam skor $<3$ ise hasta haftada bir tekrar değerlendirilmesi gerektiği anlamına gelir. Eğer majör operasyon planı varsa yine bir nütrisyon planı geliştirilmesi gerektiği belirtilmektedir [17].

\subsection{Araștırmanın Etiği}

Araştırmanın yapılabilmesi için XXX girişimsel olmayan klinik araştırmaları etik kurulundan onay alınmıştır. Araştırmanın yürütüleceği kurumdan yazılı izin, alınmıştır. Araştırmanın amacı, süresi, uygulanması, verilerin toplanması, araştırmaya katılmanın gönüllülüğe bağlı olduğu, araştırmadan istedikleri zaman ayrilabilecekleri ve isimlerinin saklı tutulacağına dair bilgi verildikten sonra hastalardan yazılı ve sözel onay alınmıştır.

\section{Bulgular ve Tartışma \\ 3.1.Bulgular}

Çalışmaya katılan hastaların yaş ortalaması $65,72 \pm 20,79$ (min=18, maks=94) olup \%50,4'ünün kadın, \%64,2'sinin ilkokul mezunu olduğu belirlendi. Katılımcıların $\% 72,4$ 'ünde kırık tanısı bulunuyordu, \%52,8'si ameliyat sonrası dönemdeydi ve ameliyat olanlar ile görüşülen günün ortalamas1 $5,5 \pm 30 \quad(\min =1, \quad$ maks $=30)$ 'du. Hastaların \%78'i sigara içmiyordu, \%58,5'i komorbiteye sahipti (Diyabet, Hipertansiyon, Kalp yetmezliği), Hastaların hastanedeki kilo ortalaması 73,76 $\pm 17,94$, BKI değeri 27,52 \pm 7,06'ydi. Katılımcılardan ameliyat olan hastaların ameliyat öncesi aç kalma süre ortalaması $10,82 \pm 3,20$ saat olup ameliyat sonrası aç kalma süre ortalamaları ise $11,01 \pm 10,84$ saat olarak saptand .
Ameliyat olan hastaların ameliyattan ortalama $47,23 \pm 30,33$ saat sonra ilk defa mobilize edildiği belirlendi. Kat1lımc1ların \%17,1'inde enfeksiyon geliştiği belirlendi. Çalışmaya katılan hastaların albumin değerlerinin ortalaması 3,29 $\pm 0,74$ olarak belirlendi. Hastalarının \%31,7'sinin NRS Skorunun $(\geq 3)$ olduğu (Malnütriyon riski), \%58,5'sinin ise herhangi bir diyet uygulamadığı saptand. Veri toplama süresince çalışmaya katılan hastaların tamamı beslenme desteği almıyordu. Hastaların tanıtıcı ve klinik özellikleri Tablo 1 'de verilmiştir.

Çalışmaya katılan ortopedi hastalarının NRS skorları ile yaşları arasında istatiksel olarak anlamlı bir fark saptanmış olup ( $\mathrm{t}=-4,087, \mathrm{p}=0,000)$, malnütrisyon riski olan hastaların yaş ortalaması daha yüksekti. Malnütriyon riski (NRS skoru $\geq 3$ ) olan hastaların ameliyat öncesi aç kalma süreleri, riski olmayanlara (NRS skoru <3) göre daha uzundu ( $\mathrm{t}=-3,019, \mathrm{p}=0,000)$. Ameliyat olup malnütrisyon riski olan hastaların ameliyat sonrası ilk mobilizasyonları, riski olmayan hastalara göre daha uzun sürede gerçekleşmişti ( $\mathrm{t}=-$ $4,113, p=0,000)$. Ayrıca tüm hastaların albumin değerleri ile NRS skorları arasında istatiksel olarak anlamlı bir fark saptand $1(t=5,751, p=0,000)$. NRS skoru $\geq 3$ üzerinde olan hastaların albumin değerlerinin ortalamaları daha düşüktü. Hastaların NRS skoru ile ameliyat sonrası aç kaldıkları süre ve BKİleri arasında istatiksel olarak anlamlı bir fark yoktu ( $\mathrm{t}=-1,397, \mathrm{p}=0,167 ; \mathrm{t}=-0,292$, $\mathrm{p}=0,771$ ) (Tablo 2).

Çalışmaya katılan hastalarda cinsiyete göre NRS skorları arasında istatiksel olarak anlamlı bir fark vard $1\left(X^{2}=4,809 p=0,028\right)$. Hastaların NRS skorları ile eğitim düzeyleri arasında istatiksel olarak anlamlı bir fark olduğu saptand1 $\left(\mathrm{X}^{2}=10,358, \mathrm{p}=0,0016\right)$. Kronik hastalık varlığ 1 ile NRS skoru arasında istatiksel olarak anlamlı bir fark vardı $(\mathrm{t}=5,890 \mathrm{p}=0,015)$. Çalışmaya katılan hastalardan enfeksiyonu olma durumu ile NRS skorları arasında istatiksel olarak anlamlı bir fark vardı $\left(\mathrm{X}^{2}=7,566, \mathrm{p}=0,006\right)$. Ortopedi hastalarının NRS skoru ile tanılar1, ameliyat olma durumlar1, diyetlerinin olmasının ve sigara kullanımları arasında istatiksel olarak anlamlı bir fark yoktu ( $\mathrm{p}>0,01)$. (Tablo 2).

\subsection{Tartışma}

ESPEN tek başına açlık, hastalık veya ileri yaşlanma (>80 yaş) veya bunların kombinasyonları sonucu malnütrisyon gelişebileceğini belirtmektedir [4]. Ortopedi hastalarının büyük çoğunluğunun yaşı olması ve major cerrahi planlanması bu grubun malnütrisyon riski açısından öncelikli olarak değerlendirilmesi gereksinimini ortaya çıkarmaktadır [1,9]. Çalışmamızda ortopedi hastalarının malnütrisyon prevelansının yüksek olması $(\% 31,7)$ diğer çalışmaların sonuçları ile (\%15-50) benzerdir $[1,7,8,15,18]$. Güncel kanitlarda elektif major cerrahilerde ameliyat öncesinde mutlaka beslenme durumunun değerlendirilmesini ve beslenme yetersizliği saptanan hastalarda girişimin ertelenerek ([7-10 gün süre ile), beslenme durumunun düzeltilmesini önerilmektedir [12,17].

Tablo 1. Hastaların Tanıtıcı ve Klinik Özelliklerinin Dağılımı (n=123) 


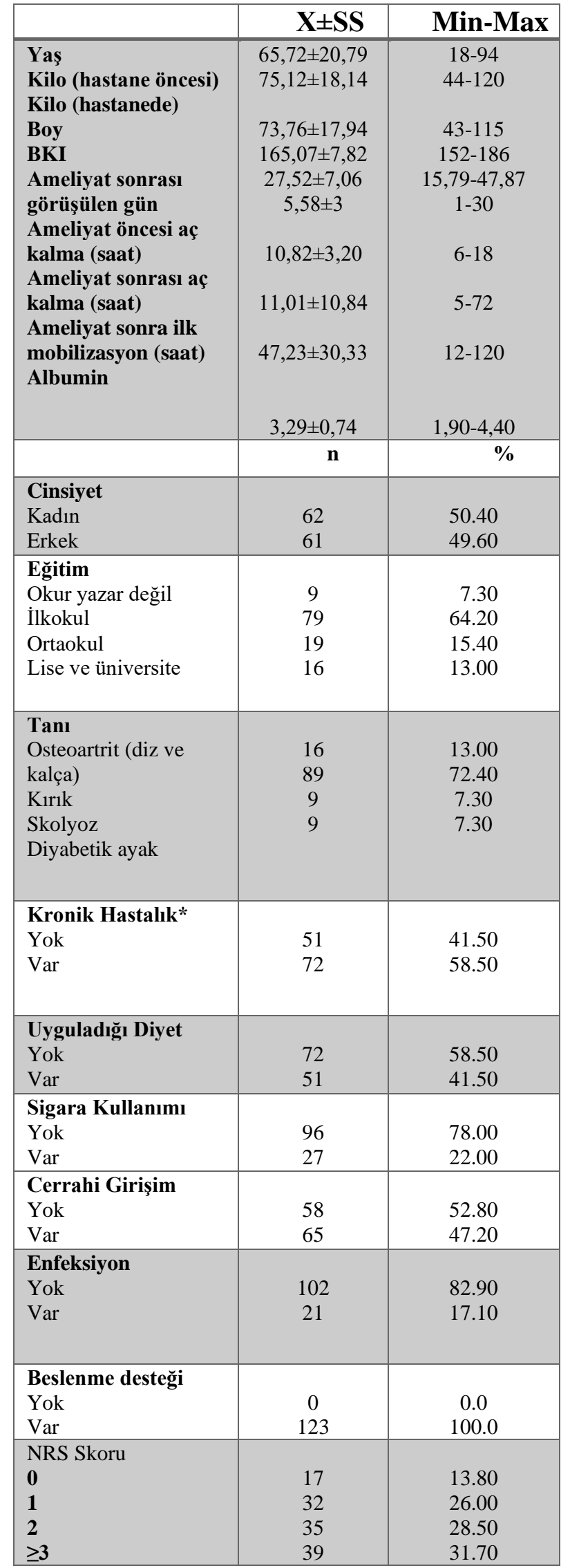

DM, HT, Kalp Yetmezliği
Hastaların yatış sırasında bir tarama aracının kullanılması ile malnütrisyonlu hastaların \%50-80'inin tanımlanabileceği, erken tarama ve tedavi ile hastanede yatış süresinin kısalabileceği belirtilmektedir [19]. Çalışmamızda hastaların beslenme durumları ESPEN ve KEPAN'ın da önerdiği değerlendirme araçlarından birisi olan NRS aracı ile değerlendirilmiş olup, beslenme yetersizliği riski yaş, ameliyat öncesi aç kalma süresi, albümin düzeyleri ve ameliyattan sonra aç kalma süreleri ile anlamlı düzeyde ilişkili bulunmuştur [4,12,17].

Çalışmamızda malnütriyon riski yüksek olan ortopedi hastalarının yaş ortalaması daha yüksektir. Kaiser ve ark [2010], yaşlı yetişkinler arasında malnütrisyon sıklığını belirlemek amacıyla yaptıkları çalışmada, yaşlı yetişkinlerin \%23'ünün malnütrisyonlu, $\% 46$ 'sının ise malnütrisyon riski altında olduğunu belirtmektedirler [20] Ortopedik cerrahi girişimlerin sıklıkla yaşlı bireylerde uygulanıyor olması, ortopedi kliniklerinde yatan yaşlı hastalar arasında da malnütrisyon riskinin fazlalığını açıklamaktadır [12,14]. Ihle ve arkadaşları (2017), ortopedik cerrahi geçiren yaşlı hastalarda malnütrisyon oranının \%32-60 arasında değişmekte olduğunu saptamışlardır. Yaşlılardaki malnütrisyon; otonomi kaybına, yaşam kalitesinde azalmaya, hastane başvurularında artışa, hastanede kalış süresinde uzamaya, enfeksiyonlara, yara iyileşmesinde gecikmelere, yürüyüş bozuklukları ile düşme ve kırıklara, zamansız ölümlere neden olan patolojik durumlarla yakından ilişkilidir [1,21]. Çalışmamızda kadın hastaların erkek hastalara göre daha fazla malnütrisyon riski altında olduğu saptanmıştır. Çalışmamıza benzer şekilde kadınların erkeklerden daha fazla malnütrisyon açısından etkilendiğini belirten çalışmalar olduğu gibi $[14,18]$ cinsiyetin etkilemediğini belirten bir çalışma da bulunmaktadır [22].

Çalışmamızda malnütrisyon riski olan hastalar olmayanlara göre anlamlı derecede daha fazla komorbiditeye sahiptir. Prasad ve ark [2010] birden fazla komorbiditesi olan tüm hastaların \%86'sının malnütrisyon açısından riskli olduğunu göstermiştir [23]. Kronik hastalık çeşitliliği beraberinde polifarmasiyi de getirmektedir [24,25]. Yaşlı bireylerde; mide asit sekresyonunda, mide sıvısı miktarında, mide kan akımında, mide-bağırsak motilitesinde, mide boşaltım hızında, tükürük salgısında azalmalar, ilaçların farmakokinetiğinde değişikliklere neden olabildiği gibi aynı zamanda azalmış rezorpsiyon ve ilacın neden olduğu ishal nedeniyle besinin emiliminde bozulmaya, iştahsızlığa da yol açabilir [22,26]. Yaşlı bireylerde komorbit hastalıkların yönetimi için beslenme düzeni ve diyet gerekmektedir [27]. Çalışmamızda katılımcıların \%41,5'i uyguladıkları bir diyetin olduğunu belirtmiştir. Kişilerin komorbit hastalıkları için uyguladıkları bu diyetlerin uygunluğu önemlidir. Çalışmamızda kişilerin diyetlerinin olması ile malnütrisyon riskleri arasında anlamlı fark saptanmamış olup, kişilerin diyetine ne kadar uydukları ayrıntılı bir şekilde değerlendirilmemiştir. Ancak literatürde, kronik hastalığa sahip olan bireylerin diyet uyumlarının eğitim seviyesi düşük olanlarda daha kötü olduğu 
Tablo 2. Hastaların NRS Skorlarının Demografik ve Klinik Özelliklerine Göre Karşılaştırılması (n=123)

\begin{tabular}{|c|c|c|c|c|}
\hline \multirow[t]{2}{*}{ DEĞIŞKENLER } & \multicolumn{2}{|c|}{ NRS } & \multirow[b]{2}{*}{ Test (t) } & \multirow[b]{2}{*}{$\mathrm{p}$} \\
\hline & $\begin{array}{r}\text { NRS skoru }<3 \\
(\mathbf{n}=\mathbf{8 4}) X \pm S S\end{array}$ & $\begin{array}{c}\text { NRS skoru } \geq 3 \\
(n=39) X \pm S S\end{array}$ & & \\
\hline Yaş & $56,11 \pm 3,67$ & $74,47 \pm 2,88$ & $-4,087$ & $\mathbf{0 , 0 0 0 *}$ \\
\hline BKI & $21,12 \pm 6,30$ & $27,53 \pm 8,54$ & $-0,292$ & 0,771 \\
\hline $\begin{array}{l}\text { Ameliyat öncesi aç } \\
\text { kalma süresi }\end{array}$ & $10,24 \pm 0,40$ & $12,39 \pm 0,72$ & $-3,019$ & $\mathbf{0 , 0 0 0 *}$ \\
\hline $\begin{array}{l}\text { Ameliyat sonrası aç } \\
\text { kalma süresi }\end{array}$ & $9,71 \pm 0,93$ & $13,56 \pm 3,41$ & $-1,397$ & 0,167 \\
\hline Mobilizasyon & $37,51 \pm 3,09$ & $66,26 \pm 7,07$ & $-4,113$ & $0,000 *$ \\
\hline Albumin & $3,61 \pm 0,09$ & $2,86 \pm 0,12$ & 5,751 & $0,000^{*}$ \\
\hline & n $(\%)$ & n $(\%)$ & Test $\left(\mathbf{x}^{2}\right)$ & \\
\hline $\begin{array}{l}\text { Cinsiyet } \\
\text { Kadın } \\
\text { Erkek }\end{array}$ & $\begin{array}{l}36(59,0) \\
48(77,4)\end{array}$ & $\begin{array}{l}25(41,0) \\
14(22,6)\end{array}$ & 4,809 & $0,028 *$ \\
\hline $\begin{array}{l}\text { Eğitim } \\
\text { Okur-Yazar değil } \\
\text { İlkokul } \\
\text { Ortaokul } \\
\text { Lise ve üzeri }\end{array}$ & $\begin{array}{l}3(33,3) \\
51(64,6) \\
17(89,5) \\
13(81,3)\end{array}$ & $\begin{array}{l}6(66,7) \\
28(35,4) \\
2(10,5) \\
3(18,8) \\
\end{array}$ & 10,358 & $0,016 *$ \\
\hline $\begin{array}{l}\text { Tanı } \\
\text { Osteoartrit } \\
\text { Kırık } \\
\text { Skolyoz } \\
\text { Diyabetik ayak }\end{array}$ & $\begin{array}{l}9(60) \\
63(70) \\
5(55,6) \\
7(77,8)\end{array}$ & $\begin{array}{l}6(40) \\
27(30) \\
4(44,4) \\
2(22,2)\end{array}$ & 1,776 & 0,656 \\
\hline $\begin{array}{l}\text { Cerrahi Girişim } \\
\text { Var } \\
\text { Yok }\end{array}$ & $\begin{array}{l}42(64,6) \\
42(72,4)\end{array}$ & $\begin{array}{l}23(35,4) \\
16(27,6)\end{array}$ & 0,861 & 0,354 \\
\hline $\begin{array}{l}\text { Kronik Hastalık } \\
\text { Yok } \\
\text { Var }\end{array}$ & $\begin{array}{l}41(80,4) \\
43(59,7)\end{array}$ & $\begin{array}{l}10(19,6) \\
29(40,3)\end{array}$ & 5,890 & $0,015^{*}$ \\
\hline $\begin{array}{l}\text { Diyet } \\
\text { Yok } \\
\text { Var }\end{array}$ & $\begin{array}{l}52(61,9) \\
32(62,7) \\
\end{array}$ & $\begin{array}{l}20(27,8) \\
19(37,3) \\
\end{array}$ & 1,238 & 0,266 \\
\hline $\begin{array}{l}\text { Sigara } \\
\text { Yok } \\
\text { Var }\end{array}$ & $\begin{array}{l}66(68,8) \\
18(66,7) \\
\end{array}$ & $\begin{array}{l}30(31,3) \\
9(33,3)\end{array}$ & 0,042 & 0,837 \\
\hline $\begin{array}{l}\text { Enfeksiyon } \\
\text { Yok } \\
\text { Var }\end{array}$ & $\begin{array}{l}75(73,5) \\
9(42,9)\end{array}$ & $\begin{array}{l}27(26,5) \\
12(57,1) \\
\end{array}$ & 7,566 & $0,006 *$ \\
\hline
\end{tabular}

belirtilmektedir [28,29]. Çalışmamızdaki hastaların yaklaşık üçte ikisinin düşük eğitim düzeyine sahip olduğu ve eğitim düzeyine göre NRS skorları arasında anlamlı fark olduğu göz önünde bulundurulduğunda, bireylerin diyetlerine uygun davranmamış olabilecekleri düşünülmüştür. $\mathrm{Bu}$ durum eğitim seviyesi düşük olan bireylerde malnütrisyon riskinin arttırabilir.

Bu çalışmada malnütriyon riski olan hastaların ameliyat sonrası mobilizasyon süreleri daha uzun sürede gerçekleşmiştir. Hollanda'da huzurevi sakinleri üzerinde yapılan bir çalışmada, yetersiz beslenen hastaların artmış yatağa bağımlılık ve tekerlekli sandalye bağımlılık seviyesine sahip olduğu görülmektedir [30]. Maurer ve arkadaşları çalışmasında da malnütriyon riski olan hastaların yardımcı araç kullanma oranının daha yüksek olduğu belirtmektedir [18]. Ayrıca, araştırmalar yetersiz beslenmenin kas kütlesini azaltabileceğini ve sarkopeni riskini artırabileceğini göstermektedir [31]. Bu olumsuz etkiler ortopedi hastalarının zaten kisıtlı olan mobilizasyonlarını olumsuz etkilemektedir. $\mathrm{Bu}$ nedenle malnütrsiyon riski saptanan hastaların beslenme desteği almaları önerilmesine [12,17] rağmen, çalışmamızda hastaların tamamının hiç beslenme desteği almadığı saptanmıştır. Wang ve ark. ise çalışmalarında ortopedi kliniğindeki hastaların \%80'inin beslenme desteği aldığını ancak bu desteğin uygun şekilde verilmediğini saptamışlardır [7] Aynı çalışmada beslenme desteklerinin profesyonel bir komite tarafından güncel 
rehberlere göre yapılması gerektiğinin önemi vurgulanmıştır. $\mathrm{Bu}$ sonuçlar ortopedi kliniklerinde gereksinimi olan hastalarda beslenme desteği kullanımı ile ilgili önemli bilgi ve uygulama eksiklikleri olduğunu düşündürmektedir.

Çalışmamızda malnütrisyon riski yüksek olan hastaların ameliyat öncesi açlık sürelerinin daha uzun olduğu belirlenmiştir. Kanıta dayalı rehberlerde ameliyat öncesi önerilen açlık süresinin belirlenmesine (6 saate kadar hafif yemek, 2 saate kadar berrak sıvılar) rağmen $[17,21,32]$ araştırmanın yürütüldüğü hastanede hastaların ameliyat öncesi dönemde genel olarak 8 saat aç kalması sağlanmaktadır. Bu çalışmada da ameliyat öncesi açlık süresi ortalaması $10.82 \pm 3.20$ saattir. Çeşitli nedenlerden (ameliyatın herhangi bir nedenle ertelenmesi, ameliyathane yoğunluğundan kaynaklı gecikme vb) dolayı da bu sürenin uzamış olabileceği düşünülmektedir. Kanıtlara rağmen, geleneksel yaklaşımla hastaların aç bırakılması söz konusudur. Ülkemizde üroloji kliniğinde yapılan bir çalışmada hastaların nerdeyse tamamının (\%95.8) ameliyattan önce en az 8 saatlik bir süre aç bırakıldığı saptanmıştır [33]. Geleneksel yaklaşımda ameliyat öncesi açlı̆̆ın hedefi bulant1, kusmanın ve aspirasyon pnömonisinin önlenmesi iken, aslında komplikasyonları önlemediği, aksine ameliyat öncesi uzamış açlık süresinin hasta sonuçlarını olumsuz etkileyeceği belirtilmektedir $[1,17,34]$. Uzamış açlığın aksine son çalışmalar ameliyat öncesi oral karbonhidrat yüklemesi uygulamasının cerrahi stres yanıtı azalttığını bildirilmektedir [4]. Diğer yandan bu çalışmada hastaların ameliyat sonrası açlık süre otalamaları $11,01 \pm 10,84$ olarak saptanmış olup, beslenme yetersizliği riski için anlamlı olmadığ belirlenmiştir. Ameliyat sonrası için de kanıtlar, başlanabilecek en erken dönemde enteral beslenmeye geçilmesini önermektedir. Böylece barsak fonksiyonlarının erken geri dönüşü, cerrahi stres yanıtın azalması, erken mobilizasyon, hastanede kalış süresinin azalması gibi yararlar sağlanabilir [17,21].

Malnütrisyonun önemli sonuçları arasında; yara iyileşmesinde gecikme, komplikasyonlarda artış, hastanede kalış süresinde uzama, morbidite, mortalite oranlarında ve bakım maliyetlerinde artma sayılabilir [35,36]. Çalışmamızda da malnütrisyon riski yüksek olan hastaların, riski olmayanlara göre enfeksiyon oranlarının daha yüksek olduğu belirlenmiştir. Yetersiz beslenmenin, yara iyileşmesi sürecinde, fibroblast proliferasyonu ve kollajen sentezinin yetersiz gerçekleşmesi sonucu inflamasyonu uzatarak hastaları cerrahi alan enfeksiyonuna yatkın hale getirdiği düşünülmektedir [32,37] Peersman ve ark. [2001] 6,489 total diz artroplastisinde 97 cerrahi alan enfeksiyonu geliştiğini ve kontrol hastaları ile karşılaştırıldığında yetersiz beslenme, obezite ve diyabet faktörlerinin bu riski artırdığını belirtmektedirler. Benzer şekilde çalışmamıza katılan hastaların yaklaşık üçte birinde malnütrisyon riski olması, ek hastalıkları arasında diyabet olması ve hastaların BKİ değerinin 27.52 olmas da enfeksiyon gelişimini tetiklemiş olabilir. Ancak çalışmamızda hastaların BKİ ileri ile malnütrisyon riskleri arasında anlamlı ilişki saptanmamıştır. Çalışmamızda beslenme yetersizliği riski saptanan hastaların (NRS $\geq 3$ ), albumin düzeylerinin ortalamasının $2,86 \pm 0,12$ olduğu (normal değer aralığ 3,4 ile $5,4 \mathrm{~g} / \mathrm{dL}$ ) saptanmıştır. Albumin, beslenme yetersizliği tanılamasında kullanılan biyokimyasal testlerden sadece bir tanesidir [3,13,17]. Albuminin düşük olması da, cerrahi süreçte gelişecek negatif nitrojen dengesi sonucu yara iyileşmesinde rol alacak protein yapısındaki komplemanların yetersizliği sonucu yara iyileşmesinde gecikme ve yara enfeksiyonu ile sonuçlanabilir [2,32,37]. Araştırmamızda hastaların tanılarının malnütrisyon riskini belirlemede etikileyici faktör olmadığı saptanmıştır. Ihle ve arkadaşları (2017) 1055 ortopedi hastasının beslenmelerini değerlendirdikleri çalışmada en yüksek malnütrisyon oranının kırığı olan yaşlı hastalarda saptamışlardır [1]. Bizim çalışmamızda da örneklem grubunun büyük çoğunluğunu $(\% 72,4)$ kırığı olan hastalar oluşturmakta olup bu hastaların \%27'sinde malnütrisyon riski saptanmıştır. Çalışmamızda ameliyat olma durumunun da malnütrisyon riskini için belirleyici faktör olmadığ belirlenmiştir. Wank ve ark [2016] çalışmasında ortopedi kliniğinde yaklaşık her dört hastadan birinde $(\% 24,3)$ malnütrisyon ya da riskinin yatış anında mevcut olduğunu saptamışlardır [7]. Ayrıca aynı çalışmada hastaların taburculuk aşamasında malnütrisyon ya da risklerinin \%40'a yükseldiğini de bildirmişlerdir Ortopedi hastalarında yaşla ilişkili malnütrisyon riski faktörlerinin değerlendirildiği çalışmada, 70 yaş ve üzerindeki hastalarda, cerrahi girişim geçirmeseler de, komorbit hastalık ve yaşam tarzıyla ilişkili faktörlerin [bakımevinde kalma, daha az sebze ve fazla ekmek tüketimi, düşük fiziksel aktivite ve sigara içme] etkili olduğunu belirtmişlerdir [38]. Bu çalışmada sigara kullanımının, malnütrisyon riskini belirlemede etkileyici faktör olmadığı saptanmıştır.

\section{Sonuc}

Çalışmamızda yaklaşık üç hastadan birinin malnütriyon riski altında olduğu saptanmış olup, yaş ortalaması yükseldikçe malnütrisyon riskinin arttığı belirlenmiştir. Araştırma sonuçlarımız hastaların malnütrsiyon riskini etkileyen diğer seçilmiş faktörlerin cinsiyet, hastaların eğitim düzeyi, komorbit hastalık varlığı, düşük albumin düzeyi, ameliyat öncesi açlık süresi ve ameliyat sonrası enfeksiyon gelişmesi olduğunu göstermiştir. Ayrıca malnütrisyon riski olan hastaların ameliyat sonrası ilk mobilizasyon sürelerinin daha geç olduğu saptanmıştır. Çalışmamızda ameliyat öncesi ve sonrası açlık sürelerinin de kanıtların önerileriyle uyuşmadığı ve hastaların tamamının beslenme desteği almadığı belirlendi. Çalışmamızdan elde ettiğimiz sonuçlar doğrultusunda Ortopedi kliniğindeki hastaların beslenmelerinin değerlendirilmesinin önemli olduğunu vurgulayabiliriz. Yaşı nüfusun artması ile birlikte ortopedik cerrahide yaşlı beslenmesi daha da önemli hale gelmektedir. $\mathrm{Bu}$ bağlamda güncel rehberler doğrultusunda, profesyonel bir ekip yaklaşımı ile beslenme desteği yaklaşımları standart haline 
getirilmelidir. Cerrahi öncesi kısa açlığın ve sonrası erken enteral beslenmenin klinik rutinlerinde yer alması ve ekibin buna uyum göstermesi için hizmet içi eğitimler planlanması önerilmektedir.

\section{References}

1.Ihle, C, Freude, T, Bahrs, C, Zehendner, E, Braunsberger, J, Biesalski, H.K, et al., Malnutrition - An underestimated factor in the inpatient treatment of traumatology and orthopedic patients: A prospective evaluation of 1055 patients, Injury, 2017, 48(3), 628-36.

2.Bell, J.J, Pulle, R.C, Crouch, A.M, Kuys, S.S, Ferrier, R.L Whitehouse S.L, Impact of malnutrition on 12-month mortality following acute hip fracture, ANZ Journal of Surgery, 2016 , 86(3),157-61.

3. Kondrup, J, Ramussen, H.H, Hamberg, O, Stanga, Z, Camilo, M Richardson, R, et al. Nutritional risk screening (NRS 2002): A new method based on an analysis of controlled clinical trial, Clinical Nutrition, 2003, 22(3), 321-36.

4. Cederholm, T, Bosaeus, I, Barazzoni,, R, Bauer J, Van Gossum,, A, Klek S, et al, Diagnostic criteria for malnutrition - An ESPEN Consensus Statement, Clinical Nutrition, 2015, 34(3), 335-40.

5. Meijers, J.M.M, van Bokhorst-de van der Schueren, M.A.E, Schols, J.M.G.A, Soeters, P.B, Halfens, R.J.G, Defining malnutrition: Mission or mission impossible? Nutrition, 2010, 26(4), 432-40.

6. Geurden, B, Franck, E, Weyler, J, Ysebaert, D, The risk of malnutrition in community-living elderly on admission to hospital for major surgery, Acta Chirurgica Belgica, 2015, 115(5), 341-7.

7. Wang, N, Dong, Y.L, Huo, T, Shao, Y, Xing, W, Li, S, Nutritiona risk, malnutrition and nutritional support among hospitalized patients in orthopedics/spinal surgery of a Hohhot teaching hospital, Asia Pacific Journal of Clinical Nutrition, 2016, 25(2), 273-82.

8. Deren, M.E, Huleatt, J, Winkler, M.F, Rubin, L.E, Salzler, M.J, Behrens, S.B, Assessment and Treatment of Malnutrition in Orthopaedic Surgery. JBJS Reviews, 2014, 2(9), 1.

9. Thomas, M.N, Kufeldt, J, Kisser, U, Hornung, H.M, Hoffmann, J, Andraschko, M, et al., Effects of malnutrition on complication rates, length of hospital stay, and revenue in elective surgical patients in the G-DRG-system, Nutrition, 2016, 32(2), 249-54

10. Felder ,S, Lechtenboehmer, C, Bally, M, Fehr, R, Deiss, M, Faessler $\mathrm{L}$, et al., Association of nutritional risk and adverse medical outcomes across different medical inpatient populations, Nutrition, 2015 31(11-12), 1385-93.

11. Khalatbari-Soltani, S, Marques-Vidal, P, The economic cost of hospital malnutrition in Europe; a narrative review, Clinical Nutrition ESPEN, 2015, 10(3), 89-94.

12. Koren-Hakim, T, Weiss, A, Hershkovitz, A, Otzrateni, I, Anbar, R, Gross Nevo, R.F, et al., Comparing the adequacy of the MNA-SF, NRS-2002 and MUST nutritional tools in assessing malnutrition in hip fracture operated elderly patients, Clinical Nutrition, 2016, 35(5), 1053-8.

13. Bohl, D.D, Shen, M.R, Hannon, C.P, Fillingham, Y.A, Darrith, B, Valle, C.J.D, Serum albumin predicts survival and postoperative course following surgery for geriatric hip fracture, The Journal of Bone and Joint Surgery, 2017, 99(24), 2110-8.

14. Ferhatoğlu, S.Y, Dönmez, N.F, The effect of nutritional status on length of hospital stay in adult patients undergoing elective orthopedic surgery: a prospective analysis, Haseki Tıp Bülteni, 2020 58, 228-33.

15. Ihle, C, Weiß, C, Blumenstock, G, Stöckle, U, Ochs, B.G, Bahrs, C, et al., Interview based malnutrition assessment can predict adverse events within 6 months after primary and revision arthroplasty - A prospective observational study of 351 patients, BMC Musculoskele Disorders, 2018, 19(1), 1-11.

16. Black, C.S, Goltz, D.E, Ryan, S.P, Fletcher, A.N, Wellman, S.S Bolognesi, M.P, et al., The Role of Malnutrition in Ninety-Day Outcomes After Total Joint Arthroplasty, Joint Arthroplasty, 2019, 34(11), 2594-600.

17. Weimann, A, Braga, M, Carli, F, Higashiguchi, T, Hübner, M, Klek, $\mathrm{S}$, et al., ESPEN guideline: Clinical nutrition in surgery, Clinical Nutrition, 2017, 36(3), 623-50.

18. Maurer, E, Wallmeier, V, Reumann, M.K, Ehnert, S, Ihle, C, Schreiner. A.J, et al., Risk of malnutrition in orthopedic trauma patients with surgical site infections is associated with increased morbidity and mortality - a 3-year follow-up study, Injury, 2020,
51(10), 2219-29.

19. Kruizenga, H.M, Van Tulder, M.W, Seidell, J.C, Thijs, A, Ader, H.J, Van Bokhorst-de van der Schueren, M.A, Effectiveness and costeffectiveness of early screening and treatment of malnourished patients, The American Journal of Clinical Nutrition, 2005, 82(5), 1082-9.

20. Kaiser, M.J, Bauer, J.M, Rämsch, C, Uter, W, Guigoz, Y, Cederholm, $\mathrm{T}$, et al., Frequency of malnutrition in older adults: A multinational perspective using the mini nutritional assessment, Journal of the American Geriatrics Society, 2010, 58(9), 1734-8.

21. Kehlet, H, Memtsoudis, S.G., ERAS guidelines for hip and knee replacement-need for reanalysis of evidence and recommendations?, Acta Orthopaedica et Traumatologica Turcica, 2020, 91(3), 243-5.

22. Dominguez, R.J, Burden of malnutrition in a tertiary care hospital in baguio city, SAGE Open, 2013, 3(3), 1-7.

23. Prasad, N, Gupta, A, Sinha, A, Sharma, R.K, Saxena, A, Kaul, A, et al., Confounding effect of comorbidities and malnutrition on survival of peritoneal dialysis patients, Journal of Renal Nutrition, 2010, 20(6), 384-91.

24. Arslan, M, Arslan Keskin, E, Koç, E, Sözmen, M, Kaplan, Y, Altmış beş yaş ve üzeri kişilerde kırılganlık ile ilaç kullanımı ve polifarmasi arasındaki ilişki, Haseki Tıp Bülteni, 2020, 58, 33-41.

25. Elkin, N, Yaşlılarda Polifarmasi ve akılcı ilaç kullanımına aile hekimliği yaklaşımı, IGUSABDER, 2020, 11, 279-90.

26. Herr, M, Robine, J.M, Pinot, J, Arvieu, J.J, Ankri, J, Polypharmacy and frailty: Prevalence, relationship, and impact on mortality in a French sample of 2350 old people, Pharmacoepidemiol Drug Safety, 2015, 24(6), 637-46.

27. Kubat Bakir, G, Akin, S, Yaşl1lıkta kronik hastalıkların yönetimi ile ilişkili faktörler, Sağlık ve Toplum, 2019, 2, 17-25.

28. Türten Kaymaz, T, Akdemir, N, Diyabetli Bireylerde Hastalığa Psikososyal Uyum, Psikiyatr Hemşireliği Dergisi, 2016,7(2),61-7.

29. Baykal, A, Kapucu, S, Tip 2 diyabetes mellituslu hastaların tedavilerine uyumlarının değerlendirilmesi, Hacettepe Üniversitesi Hemşirelik Fakültesi Dergisi, 2015,2(2),44-58.

30. Neyens, J, Halfens, R, Spreeuwenberg, M, Meijers, J, Luiking, Y, Verlaan, G, et al, Malnutrition is associated with an increased risk of falls and impaired activity in elderly patients in Dutch residential long-term care (LTC): A cross-sectional study, Archives of Gerontology and Geriatrics, 2013,56(1),265-9.

31. Tominaga, H, Oku, M, Arishima, Y, Ikeda, T, Ishidou, Y, Nagano, S, et al., Association between bone mineral density, muscle volume, walking ability, and geriatric nutritional risk index in hemodialysis patients, Asia Pacific Journal of Clinical Nutrition, 2018, 27(5), 1062-6.

32. Bozic, K.J, Lau, E, Kurtz, S, Ong, K, Rubash, H, Vail, T.P, et al Patient-Related risk factors for periprosthetic joint infection and postoperative mortality following total hip arthroplasty in medicare patients, The Journal of Bone and Joint Surgery, 2012, 94(9), 794 800 .

33. Kankiliç, R, Tuna, A, Transüretral rezeksiyon-prostat (tur-p) ameliyatlarında eras protokolü ile ameliyat öncesi ve sonrası yapılması gereken beslenme, ağrı ve erken mobilizasyon uygulamalarının karșılaştırılması, Kahramanmaraş Sütçü İmam Üniversitesi Tip Fakültesi Dergisi, 2019, 14(2), 69-72.

34. Gök, F, Van Giersbergen, M, Ameliyat öncesi aç kalma: Sistematik derleme Preoperative fasting: A systematic review, Pamukkale Tlp Dergisi, 2018, 11(2), 183-94.

35. Shpata, V, Prendushi, X, Kreka, M, Kola, I, Kurti, F, Ohri, I Malnutrition at the time of surgery affects negatively the clinical outcome of critically ill patients with gastrointestinal cancer, Medical Archieves, 2014, 68(4), 263-7.

36. Mignini, E.V, Scarpellini, E, Rinninella, E, Lattanzi, E, Valeri, M.V Clementi, N, et al., Impact of patients nutritional status on major surgery outcome, European Review for Medical and Pharmacological Sciences, 2018, 22(11), 3524-33.

37. Guo, J.J, Yang, H, Qian, H, Huang, L, Guo, Z, Tang, T, The Effects of different nutritional measurements on delayed wound healing after hip fracture in the elderly, Journal of Surgical Research, 2010, 159(1), 503-8.

38. Lambert, C, Nüssler, A, Biesalski, H.K, Freude, T, Bahrs, C, Ochs, $\mathrm{G}$, et al., Age-dependent risk factors for malnutrition in traumatology and orthopedic patients, Nutrition, 2017, 37, 60-7. 
http://edergi.cbu.edu.tr/ojs/index.php/cbusbed isimli yazarın CBU-SBED başlıklı eseri bu Creative Commons

Alınt1-Gayriticari4.0 Uluslararası Lisansı ile lisanslanmıştır.

(c) (7) \& 